\title{
AKTIVITAS BANCASSURANCE DALAM DUNIA PERBANKAN: ADAKAH PRAKTIK BUNDLING YANG MELANGGAR HUKUM PERSAINGAN USAHA?
}

\author{
Indirani Wauran-Wicaksono \\ Staf Pengajar Fakultas Hukum Universitas Kristen Satya Wacana, \\ Korespondensi: indirani.wauran@staff.uksw.edu
}

\begin{abstract}
Abstrak
Perusahaan asuransi mengembangkan strategi pemasaran yang disebut dengan bancassurance. Penamaan ini sesungguhnya terkait dengan strategi penggabungan kerjasama antara produk bank dan asuransi. Berdasarkan SE BI No.12/35/DPNP tanggal 23 Desember 2010, aktivitas bancassurance terdiri dari beberapa kategori; dari kategori tersebut terdapat jenis bancassurance yang termasuk dalam pure product bundling atau yang serig disebut tying. Jenis budling yang seperti ini berada dibawah pengaturan mengenai exclusive dealing yang pada dasarnya dilarang oleh UU Anti Monopoli walaupun dengan menggunakan pendekatan rule of reason. Mempertimbangkan kondisi penguasaan pasar asuransi (market share) oleh perusahaan asuransi pada saat ini, dapat dikatakan bahwa pure product bundling atau tying yang terjadi pada aktivitas bancassurance tidak melanggar UU Persaingan Usaha. Namun demikian, ada kemungkinan kecil dapat menciptakan situasi monopoli dan persaingan usaha tidak sehat sehingga melanggar UU Persaingan Usaha.
\end{abstract}

Kata-kata Kunci: Bancassurance; Exclusive Dealing; Bundling; Monopoli.

\begin{abstract}
Insurance companies develop marketing strategies to promote their product called bancassurance. According to the SE BI No. 12/35/DPNP dated December 23, 2010, bancassurance had some category. Furthermore, it is known that there is a kind of bancassurance that included in the category of pure product bundling or often referred as tying. This bundling categories fall under exclusive dealing provision that basically prohibited by the Competition Act, with rule of reason approach. By considering the current condition of the insurance company's market share, it could be said that pure product bundling or tying in bancassurance is not infringe competition law however have a very small potential to creates monopolistic practices and unfair business competition, therefore violating Competition Law.
\end{abstract}

Key Words: Bancassurance; Exclusive Dealing; Bundling; Monopoly. 


\section{PENDAHULUAN}

Bancassurance adalah produk asuransi yang dikembangkan dan didistribusikan melalui jaringan bank. Bisnis ini berbentuk kerja sama antara pihak bank dan pihak asuransi tanpa mengambil alih produk-produk asuransi.

Pada tanggal 2 April 2014, untuk pertama kalinya KPPU menggelar sidang terkait kasus bancassurance. ${ }^{1}$ Dalam perkara Nomor 05/KPPU-I/201, PT. Bank Rakyat Indonesia, Tbk., (Persero) (Terlapor I), yang melakukan perjanjian bancassurance dengan PT. Asuransi Jiwa Bringin Jiwa Sejahtera (Terlapor II) dan PT. Heksa Eka Life Insurance (Terlapor III) dilaporkan karena diduga melakukan pelanggaran Pasal 15 ayat (2) dan/atau Pasal 19 huruf a UndangUndang Nomor 5 Tahun 1999 tentang Larangan Praktik Monopoli dan Persaingan Usaha Tidak Sehat (UU Persaingan Usaha). Perkembangan praktik bancassurance membuat otoritas pengawas perbankan menghimbau agar bancassurance terbuka bagi asuransi lain, artinya tidak ada perjanjian eksklusif antara satu asuransi tertentu dengan pihak bank. ${ }^{2}$ Pertanyaannya adalah apakah benar strategi pemasaran produk asuransi dalam bancassurance berpotensi melanggar hukum persaingan usaha.
Tulisan ini hendak menganalisis hal tersebut dengan terlebih dahulu membahas mengenai apa itu bancassurance, kemudian dilanjutkan dengan analisis mengenai praktik bundling dalam bancassurance. Penjualan secara bundling terjadi ketika produk bank dan produk asuransi sebagai dua produk yang terpisah dijual secara bundle. Dalam kategori jenis bancassurance yang dibuat oleh Bank Indonesia (BI) diketahui bahwa terdapat jenis bancassurance yang merupakan pure bundling atau disebut juga tying. Kemudian pada bagian selanjutnya akan dianalisis apakah pure bundling atau tying dalam bancassurance melanggar hukum persaingan usaha khususnya Pasal 15 ayat (2) UU Persaingan Usaha mengenai Perjanjian Tertutup dan Pasal 19 huruf a UU Persaingan Usaha mengenai penguasaan pasar. Mengingat pendekatan yang dipakai adalah rule of reason maka harus dibuktikan tindakan tersebut menyebabkan praktik monopoli dan persaingan usaha tidak sehat. Sampai saat ini, potensi bancassurance melanggar ketentuan tersebut sangat kecil mengingat tidak ada pelaku usaha perbankan dan/atau asuransi yang menguasai pasar. Terakhir adalah bagian penutup yang berisi kesimpulan.

Yudanov, 'Dugaan Perjanjian Tertutup dan Penguasaan Pasar oleh BRI' (2014) <http:// www.kppu.go.id/id/2014/04/dugaan-perjanjian-tertutup-dan-penguasaan-pasar-oleh-bri/> diakses 17 April 2014. Ilyas Istianur Pradita, 'Strategi Bisnis Bancassurance berpotensi picu Monopoli' (2014) <http://bisnis.liputan6.com/read/2028883/strategi-bisnis-bancassuranceri-berpotensi-picu-monopoli> diakses 17 April 2014.

2 FAT, 'OJK Minta Bancassurance Terbuka Bagi Asuransi lain. Jika Tak Terbuka Bagi Industri Asuransi Lain, maka Tidak Fair' <http://www.hukumonline.com/berita/baca/lt5333e8baeldaf/ ojk-minta-bancassurance-terbuka-bagi-asuransi-lain> diakses 17 April 2014. 


\section{PEMBAHASAN}

\section{Bancassurance Sebagai Praktik Bisnis Perbankan di Indonesia}

Bancassurance adalah aktivitas kerjasama antara bank dengan perusahaan asuransi dalam rangka memasarkan produk asuransi melalui bank. Bancassurance merupakan terobosan bagi perusahaan asuransi untuk meningkatkan nasabahnya. Hal ini bisa dimengerti mengingat hasil analisis terhadap tingkat penetrasi, density dan kontribusi asuransi menunjukkan bahwa peningkatan dan pertumbuhan asuransi di Indonesia sampai dengan sekarang masih belum mampu memberikan kontribusi yang signifikan terhadap perkembangan perekonomian nasional. ${ }^{3}$ Hal itu dapat diartikan bahwa kesadaran "berasuransi" di kalangan masyarakat Indonesia masih rendah. ${ }^{4}$

Pemahaman mengenai bancassurance dapat diperoleh dari Surat Edaran Bank Indonesia No. 12/ 35/DPNP tanggal 23 Desember 2010 perihal Penerapan Manajemen Risiko pada Bank yang Melakukan Aktivitas Kerjasama Pemasaran dengan Perusahaan Asuransi (Bancassurance). ${ }^{5}$ Yang dimaksud dengan aktivitas kerjasama pemasaran antara bank dengan perusahaan asuransi yang selanjutnya disebut bancassurance dalam Surat Edaran Bank Indonesia ini adalah aktivitas kerjasama antara bank dengan perusahaan asuransi dalam rangka memasarkan produk asuransi melalui bank. Aktivitas kerjasama ini diklasifikasikan dalam 3 (tiga) model bisnis sebagai berikut:

\section{a. Referensi}

Referensi merupakan suatu aktivitas kerjasama pemasaran produk asuransi, dengan Bank berperan hanya mereferensikan atau merekomendasikan suatu produk asuransi kepada nasabah. Peran bank dalam melakukan pemasaran terbatas sebagai perantara dalam meneruskan informasi produk asuransi dari perusahaan asuransi mitra bank kepada nasabah atau menyediakan akses kepada perusahaan asuransi untuk menawarkan produk asuransi kepada nasabah. Aktivitas ini dapat dibedakan sebagai berikut: 1) referensi dalam rangka produk bank; 2) referensi tidak dalam rangka produk bank.

Dalam aktivitas yang pertama, yaitu referensi dalam rangka produk bank, bank mereferensikan atau merekomendasikan produk asuransi yang menjadi persyaratan untuk memperoleh suatu produk perbankan kepada nasabah. Persyaratan keberadaan produk asuransi tersebut dimaksudkan untuk kepentingan dan perlindungan kepada bank atas risiko terkait dengan produk yang diterbitkan

\footnotetext{
3 Hendrisman Rahim, 'Optimisme Pertumbuhan Asuransi Indonesia; Proyeksi Perkembangan Lima Tahun (2014-2018)’ (2013) 1 Jurnal Asuransi dan Manajemen Resiko 1, 12.

4 Ibid.

5 Selanjutnya disebut SEBI No. 12/35/DPNP.
} 
atau jasa yang dilaksanakan oleh Bank kepada nasabah. Dalam hal ini, pada hakikatnya produk asuransi juga untuk melindungi debitur sebagai pihak tertanggung meskipun dalam polis dicantumkan banker's clause karena bank sebagai penerima manfaat.

Sedangkan dalam referensi tidak dalam produk bank, bank mereferensikan produk asuransi yang tidak menjadi persyaratan untuk memperoleh suatu produk perbankan kepada nasabah.

\section{b. Kerjasama Distribusi}

Kerjasama distribusi merupakan suatu aktivitas kerjasama pemasaran produk asuransi, dengan bank berperan memasarkan produk asuransi dengan cara memberikan penjelasan mengenai produk asuransi tersebut secara langsung kepada nasabah.

Peran bank tidak hanya sebagai perantara dalam meneruskan informasi produk asuransi dari perusahaan asuransi mitra bank kepada nasabah, tetapi bank juga memberikan penjelasan secara langsung yang terkait dengan produk asuransi seperti karakteristik, manfaat, dan risiko dari produk yang dipasarkan dan meneruskan minat atau permintaan pembelian produk asuransi dari nasabah kepada perusahaan asuransi mitra bank.

\section{c. Integrasi Produk}

Integrasi produk merupakan suatu aktivitas kerjasama pemasaran produk asuransi, dengan bank berperan memasarkan produk asuransi kepada nasabah dengan cara melakukan modifikasi dan/atau menggabungkan produk asuransi dengan produk bank.

Aktivitas kerjasama pemasaran ini dilakukan oleh bank dengan cara menawarkan atau menjual bundled product kepada nasabah melalui tatap muka dan/atau dengan menggunakan sarana komunikasi (telemarketing), termasuk melalui surat, media elektronik, dan website bank. Dengan demikian, peran bank tidak hanya meneruskan dan memberikan penjelasan yang terkait dengan produk asuransi kepada nasabah, tetapi juga menindaklanjuti aplikasi nasabah atas bundled product, termasuk yang terkait dengan produk asuransi kepada perusahaan asuransi mitra bank.

Terkait dengan tanggung jawab pihak bank, SEBI telah menentukan bahwa dalam penyusunan perjanjian kerjasama dalam rangka bancassurance antara bank dengan perusahaan asuransi mitra bank, wajib disusun dengan menggunakan bahasa Indonesia dan paling kurang memuat kejelasan hak dan kewajiban masing-masing pihak (bank dan perusahaan asuransi mitra bank), terutama adanya klausula yang menyatakan tanggung jawab masing-masing pihak dalam melakukan bancassurance. ${ }^{6}$ SEBI menentukan terkait dengan tanggungjawab bank pada produk asuransi antara lain sebagai berikut: 1) untuk model bisnis

6 Lihat SEBI No. 12/35/DPNP bagian II.B.2.a. 
referensi dan/atau kerjasama distribusi, bank tidak menanggung risiko atas produk asuransi yang dijual; 2) untuk model bisnis integrasi produk, bank hanya bertanggung jawab sebatas risiko dari produk bank. Selain itu, dalam perjanjian juga harus memuat secara jelas batas tanggung jawab antara bank dan perusahaan asuransi mitra bank pada setiap produk yang dipasarkan dalam hal terjadi perselisihan dengan nasabah. ${ }^{7}$

\section{Konsep Bundling dalam Hukum Persaingan Usaha}

Pada dasarnya pelaku usaha tidak dilarang untuk menjual dua atau lebih barang secara bersamaan atau menjual secara bundle. Larangan yang ditetapkan pada Pasal 15 ayat (2) UU Persaingan Usaha dengan judul Perjanjian Tertutup adalah larangan bagi pelaku usaha untuk membuat perjanjian dengan pihak lain yang memuat persyaratan bahwa pihak yang menerima barang dan atau jasa tertentu harus bersedia membeli barang dan atau jasa lain dari pelaku usaha pemasok. Sesuai dengan judul pada Pasal 15 yaitu perjanjian tertutup, maka yang menjadi pokok atau inti pengaturan pasal ini adalah adanya perjanjian.

Pasal 15 ayat (2) UU Persaingan Usaha diatas seringkali disalah mengerti sebagai larangan bagi pelaku usaha untuk melakukan penjualan dengan cara bundling. Bundling adalah penjualan dua atau lebih produk yang berbeda dalam satu paket. ${ }^{8}$ Selanjutnya juga dikatakan bahwa kata berbeda dalam pengertian bundling tersebut mengandung implikasi yang besar. Maksud dari produk yang berbeda adalah setiap produk yang dijual secara bundling pada dasarnya memiliki pangsa pasar sendiri. ${ }^{9}$ Artinya, konsumen dimungkinkan membeli masing-masing produk secara terpisah apabila produk tersebut tidak dijual secara bundle.

Secara teori, bundling sebagai strategi pemasaran dapat dibedakan menjadi dua dimensi yaitu dilihat dari the focus of bundling dan the form of bundling. ${ }^{10}$ Dari fokusnya bundling dibagi menjadi dua jenis yaitu price bundling dan product bundling. Price bundling diartikan sebagai penjualan dua atau lebih produk yang terpisah dalam satu paket dengan harga diskon, tanpa adanya integrasi kedua produk tersebut. ${ }^{11}$ Sedangkan product bundling diartikan sebagai integrasi dan penjualan dua atau lebih produk yang terpisah denga harga tertentu. ${ }^{12}$ Sedangkan dari bentuknya, bundling dapat dibedakan menjadi dua jenis yaitu pure bundling dan mixed bundling. ${ }^{13}$ Pure bundling merujuk pada penjualan dua

Lihat SEBI No. 12/35/DPNP bagian II.B.2.h.

Stefan Strernersch dan Gerard J. Tellis, 'Strategic Bundling of Products and Prices: A New Synthesis for Marketing' (2002) 66 Journal of Marketing 55, 56.

Ibid.

$10 \quad$ Ibid. 57.

Ibid. 56.

Ibid. 57.

13 Timoty Derdenger dan Vineet Kumar, 'The Dynamic Effects of Bundling as a Product Strategy' (2013) 32 Marketing Science Journal 827, 828. 
atau lebih produk hanya dalam bentuk bundle. Sedangkan mixed bundling merujuk pada praktik penjualan dua atau lebih produk dalam bentuk bundle atau dapat pula tidak dalam bentuk bundle, artinya produk-produk tersebut dapat juga dijual secara individual. Pure bundling sering pula disebut sebagau tying, yaitu adanya kewajiban bagi pembeli suatu produk untuk membeli produk lain yang diikatkan ke produk utama tersebut. ${ }^{14}$ Menurut European Commission dan US Antitrust Law, bundling dikatakan bukan merupakan tying kecuali ada pembatasan yang efektif bagi konsumen dalam memilih untuk membeli produk secara terpisah, dengan kata lain ada paksaan untuk membeli yang dialami oleh konsumen. ${ }^{15}$

Ada pula yang mengatakan bahwa tying baru ada jika suatu produk diikatkan pada produk lain yang memiliki kekuatan pasar. ${ }^{16}$ Jika salah satu produk yang di-bundling tersebut memiliki kekuatan pasar maka akan terjadi kondisi antipersaingan dan berpotensi menimbulkan monopoli.
Sampai pada titik ini dapat dipahami bahwa penjualan secara bundling bukan merupakan hal yang dilarang secara mutlak. Pedoman yang dipakai dalam menilai strategi bundling yang diterapkan adalah apakah tindakan ini berpotensi menciptakan kondisi anti persaingan dan mengakibatkan pada terjadinya monopoli. Dengan demikian, pendekatan yang digunakan dalam menilai bundling product adalah pendekatan rule of reason. Pendekatan rule of reason digunakan mengingat ada manfaat dari strategi bundling baik itu bagi konsumen maupun pelaku usaha, sehingga penafsiran yang tidak kaku layak diterapkan. ${ }^{17}$

Penggunaan rule of reason dalam tying bukan merupakan hal yang universal. sebagai contoh, dalam Microsoft Case, European Commission menggunakan pendekatan rule of reason $^{18}$ akan tetapi putusan ini kemudian dianulir oleh European Court, yang berarti European Court tetap menggunakan standar per se rule dalam tying agreement. ${ }^{19}$ Sedangkan di Amerika

14 Ibid

15 Nicholas Economides dan Ioannis Lianos, 'The Elusive Antitrust Standard on Bundling in Europe and In the United States in the Aftermath of the Microsoft Cases' (2009) 76 Antitrust Law Journal 483, 528.

16 Robert H. Bork dan J. Gregory Sidak, 'What Does The Chicago School Teach About Internet Search and the Antitrust Treatment of Google?' (2012) 8 Journal of Competition Law \& Economics 663, 598-599. Lihat juga Ahmad Adi Nugroho, 'Strategi Bundling/Tying Sebagai Upaya Abuse of Dominance: Studi Kasus Penerapan Tying/Bundling oleh Microsoft' ( 2010) 3 Jurnal Persaingan Usaha KPPU 53, 58.

17 Lampiran Peraturan Komisi Pengawas Persaingan Usaha Nomor 5 Tahun 2011 tentang Pedoman Pasal 15 (Perjanjian Tertutup) Undang-Undang Nomor 15 Tahun 1999 tentang Larangan Praktek Monopoli dan Persaingan Usaha Tidak Sehat 5. Lihat juga Ahmad Adi Nugroho, Op.Cit. 75.

18 European Commission press release of March 24, 2004, 'Commission Concludes on Microsoft Investigation, Imposes Conduct Remedies and a Fine' IP/04/382. <http://europa.eu/rapid/ $\mathrm{p} r$ e s s R e l e a s e s A c t i o n. d o ? r e f e r e $\mathrm{n} \mathrm{c}$ e $=\mathrm{I} \mathrm{P} / 0$ / $382 \&$ format=HTML\&aged=0\&language=EN\&guiLanguage=en $>$ diakses 18 April 2014 .

19 Christian Ahlborn dan David S. Evans, 'The Microsoft Judgement and its Implication for Competition Policy towards Dominant Firms in Europe' (2008) 75 Antitrust Law Journal 1, 14 <http://ssrn.com/abstract=1115867> diakses 18 April 2014. 
Serikat, untuk beberapa kasus pendekatan rule of reason digunakan dalam perkara bundling, dalam hal ini digunakan enam kriteria untuk menilai ilegalitas, sebagai berikut:

We describe the rule of reason in terms of six conditions, as follows: Bundling is iliegai under the rule of reason when it involves (I) pure bundling (2) of separate products (3) by a firm with market power. (4) involving a substantial amount of commerce, (5) which poses a threat that the bundling firm will acquire additional market power over at least one of the products that is bundled with the tying product, and (6) no plausible consumer benefits offset the potential damage to competition. ${ }^{20}$

Apabila dibandingkan, kriteria rule of reason dan kriteria pelanggaran perjanjian tertutup memiliki kriteria yang hampir sama. Perbedaannya adalah dalam kriteria perjanjian tertutup tidak ada kriteria yang keenam yaitu secara masuk akal keuntungan yang dirasakan oleh konsumen tidak dapat mengimbangi kerusakan kompetisi.

Selanjutnya, sekali lagi ditegaskan bahwa pendekatan yang dipakai untuk menilai pelanggaran Pasal 15 UU Persaingan Usaha mengenai perjanjian tertutup adalah pendekatan rule of reason, oleh karenanya harus dibuktikan bahwa strategi pemasaran yang dilakukan secara bundling dapat mengakibatkan terjadinya praktik monopoli dan atau persaingan usaha tidak sehat. ${ }^{21}$ Adapun pedoman penafsiran Pasal 15 mengenai perjanjian tertutup memberikan kriteria mengenai adanya pelanggaran perjanjian tertutup yaitu: ${ }^{22}$

a) Perjanjian tertutup yang dilakukan harus menutup volume perdagangan secara substansial atau mempunyai potensi untuk melakukan hal tersebut. Berdasarkan pasal 4, ukuran yang digunakan adalah apabila akibat dilakukannya perjanjian tertutup ini, pengusaha memiliki pangsa $10 \%$ atau lebih. ${ }^{23}$

b) Perjanjian tertutup dilakukan oleh pelaku usaha yang memiliki kekuatan pasar, dan kekuatan tersebut dapat semakin bertambah karena strategi perjanjian tertutup yang dilakukan. Ukuran kekuatan pasar adalah sesuai dengan pasal 4 yaitu memiliki pangsa pasar $10 \%$ atau lebih. ${ }^{24}$

c) Dalam perjanjian tying, produk yang diikatkan dalam suatu penjualan harus berbeda dari produk utamanya.

d) Pelaku usaha yang melakukan perjanjian tying harus memiliki kekuatan pasar yang signifikan sehingga dapat memaksa pembeli untuk membeli juga produk yang diikat. Ukuran kekuatan pasar adalah sesuai dengan pasal 4 yaitu memiliki pangsa pasar $10 \%$ atau lebih. ${ }^{25}$ Pasal 4 ayat 2 UU Persaingan Usaha "Pelaku usaha patut diduga atau dianggap secara bersamasama melakukan penguasaan produksi dan atau pemasaran barang dan atau jasa, sebagaimana dimaksud ayat (1), apabila 2 (dua) atau 3 (tiga) pelaku usaha atau kelompok pelaku usaha menguasai lebih dari 75\% (tujuh puluh lima persen) pangsa pasar satu jenis barang atau jasa tertentu."

24 Ibid. 25 Ibid.

Lihat Pasal 17 ayat (1) UU Persaingan Usaha.

Bab IV.3. Lampiran Peraturan Komisi Pengawas Persaingan Usaha Nomor 5 Tahun 2011 tentang Pedoman Pasal 15 (Perjanjian Tertutup) Undang-Undang Nomor 15 Tahun 1999 tentang Larangan Praktek Monopoli dan Persaingan Usaha Tidak Sehat 22.

Ketentuan 10\% sebagaimana dicantumkan dalam Peraturan KPPU tersebut berbeda dengan 
Ketentuan Pasal 15 UU Persaingan Usaha yang ditafsirkan dengan pedoman diatas, tidak dapat dihindarkan harus dihubungkan dengan ketentuan mengenai penguasaan pasar dalam Pasal 19 huruf a UU Persaingan Usaha yang melarang pelaku usaha baik sendiri maupun bersama pelaku usaha yang lain untuk menolak dan/atau menghalangi pelaku usaha tertentu untuk melakukan kegiatan usaha yang sama pada pasar bersangkutan apabila mengakibatkan terjadinya praktik monopoli dan persaingan usaha tidak sehat.

Sampai titik pembahasan ini diketahui bahwa praktik bundling merupakan salah satu strategi pemasaran yang boleh diterapkan oleh pelaku usaha sepanjang tidak menimbulkan praktik monopoli dan persaingan usaha yang tidak sehat. Selanjutnya menjadi pertanyaan yang akan dijawab terkait dengan tulisan ini adalah apakah strategi bancasurrance melanggar hukum persaingan usaha, akan dianalisis pada bagian dibawah ini.

Benarkah Bancasurrance sebagai Bentuk Bundling Berpotensi Menyebabkan Terjadinya Praktik Monopoli dan Persaingan Usaha Tidak Sehat?

Seperti telah disinggung pada bagian pendahuluan, KPPU mulai menyidangkan dugaan adanya perjanjan tertutup dan penguasaan pasar yang bertentangan dengan hukum persaingan usaha. Sampai saat tulisan ini dibuat, belum ada keputusan atas perkara tersebut. Tulisan ini tidak hendak menganalisis kasus bancassurance BRI yang disidangkan oleh KPPU namun praktik bancassurance secara umum.

Memperhatikan pengertian bundling sebagaimana telah diuraikan sebelumnya, maka tidak semua jenis aktivitas bank ${ }^{26}$ dalam bancassurance dapat dikategorikan sebagai bundling. Kerjasama bancassurance yang menempatkan bank dalam posisi perantara tidak dapat dikatakan sebagai bundling, sedangkan aktivitas bancassurance yang menjual produk bank dan asuransi secara bersamaan dapat dikatakan sebagai bundling.

Aktivitas kerjasama dalam bentuk referensi bukan dalam rangka produk bank dan kerjasama distribusi tidak dapat dikategorikan sebagai bundling. Hal ini dapat dijelaskan demikian, dalam bentuk kerjasama referensi tidak dalam rangka produk bank, pihak bank memberikan referensi mengenai adanya produk asuransi tertentu yang tidak menjadi persyaratan untuk memperoleh suatu produk perbankan kepada nasabah. ${ }^{27}$ Sehingga dalam hal ini, bank tidak menawarkan produk asuransi bersamaan dengan menawarkan produk bank, dengan kata lain, bank hanya menawarkan produk asuransi saja.

\footnotetext{
26 Jenis aktivitas bank dimaksud sesuai dengan kategori yang dibuat dalam SE BI No. 12/35/ DPNP.

27 Lihat Bagian I.1.a.2).SE BI No. 12/35/DPNP.
} 
Selanjutnya, dalam aktivitas kerjasama distribusi, dikatakan bahwa bank berperan memasarkan produk asuransi dengan cara memberikan penjelasan mengenai produk asuransi secara lansung kepada nasabah kemudian meneruskan minat nasabah kepada perusahaan asuransi. ${ }^{28}$ Sebagai konsekuensi logis, dalam aktivitas bancassurance referensi tidak dalam produk bank dan kerjasama distribusi, produk asuransi dijual terpisah dari produk bank dengan bank berperan seperti agen asuransi. ${ }^{29}$

Praktik bundling dapat ditemui dalam dua jenis bancassurance yaitu referensi dalam rangka produk bank dan integrasi produk. Pertama, bancassurance dengan jenis referensi dalam rangka produk bank. Bank mereferensikan atau merekomendasikan produk asuransi yang menjadi persyaratan untuk memperoleh suatu produk perbankan kepada nasabah. ${ }^{30}$ Salah satu contoh yang diberikan dalam SE BI No. 12/35/DPNP adalah kredit kendaraan bermotor yang disertai kewajiban asuransi kerugian terhadap kendaraan bermotor yang dibiayai bank. Kata kunci disini adalah adanya kewajiban produk asuransi untuk mendapatkan produk perbankan yang diinginkan nasabah, dalam hal ini kredit kendaraan bermotor. Dengan demikian produk perbankan (kredit) dan asuransi kerugian dijual secara bersamaan sebagai suatu paket. Jika dikaitkan dengan definisi bundling sebagaimana dijelaskan di atas, produk bank dan produk asuransi jelas merupakan dua jenis produk yang berbeda dan terpisah, yang kemudian dijual secara bundle. Dilihat dari the focus of bundling, jelas bahwa kerjasama bancassurance dengan jenis referensi dalam rangka produk bank merupakan bundling product. Selanjutnya, apabila dilihat dari the form of bundling maka bancassurance jenis ini merupakan pure bundling atau disebut juga tying. Dikatakan pure bundling atau tying karena produk bank tidak mungkin diperoleh tanpa membeli produk asuransi. ${ }^{31}$ Dengan demikian produk bank sebagai produk utama yang diinginkan oleh pembeli ditempatkan sebagai produk pengikat (tying product) dan asuransi sebagai produk yang oleh penjual diwajibkan untuk dibeli oleh pembeli ditempatkan sebagai produk ikatan (tied product).

Kemudian yang kedua, bancassurance dengan jenis integrasi produk. Integrasi produk merupakan bentuk kerjasama pemasaran produk asuransi dengan cara bank melakukan modifikasi dan/atau menggabungkan produk asuransi dengan produk bank, selanjutnya bank menawarkan dan/ atau menjual bundled product kepada

28 Lihat Bagian I.1.b. SE BI No. 12/35/DPNP.

29 Dikatakan seperti agen asuransi karena bank tidak bertindak untuk dan atas nama perusahaan asuransi.

30 Lihat Bagian 1.1.a.1) SE BI No. 12/35/DPNP.

31 Perlu diingat bahwa asuransi diletakkan sebagai syarat untuk mendapatkan produk bank yang diinginkan (kredit). 
nasabah. ${ }^{32}$ Dalam integrasi produk, peran bank tidak hanya memberikan penjelasan namun juga menindaklanjuti aplikasi nasabah atas bundled product, termasuk yang terkait dengan produk asuransi kepada perusahaan asuransi mitra bank. ${ }^{33}$ Dengan demikian diketahui bahwa dalam integrasi produk, bank menjual produk bank dan produk asuransi dalam satu kesatuan sebagai konsekuensi logis dari adanya modifikasi dan integrasi antara produk bank dan asuransi. Oleh karenanya BI menegaskan bahwa dalam kerjasama pemasaran jenis ini, bundled product yang dipasarkan harus dapat dipisahkan atas bagian produk yang menjadi risiko bank dan bagian produk yang menjadi resiko perusahaan asuransi mitra bank sehingga resiko masing-masing dapat diidentifikasi, diukur, dipantau, dan dikendalikan. ${ }^{34}$

BI juga membatasi bahwa integrasi produk bank hanya diperkenankan dilakukan dengan produk asuransi yang bersifat perlindungan. ${ }^{35}$ Dilihat pada pengertian bundling, jelas bahwa integrasi produk merupakan bentuk bundling karena mengintegrasikan dua produk yang berbeda kemudian dijual dalam satu paket. Dilihat berdasar kategori focus bundling, ini merupakan bundling product, dan dilihat dari bentuknya merupakan pure bundling atau disebut juga sebagai tying. Pure bundling menampakkan wujud yang jelas karena produk bank sebagai produk utama (tying product) diikat dengan produk asuransi (tied product) yang kemudian dijual sebagai satu produk. Dalam integrasi produk, nasabah bank tidak dimungkinkan membeli salah satu produk secara terpisah karena produk tersebut sudah menyatu.

Sekilas referensi dalam rangka produk bank dan integrasi produk nampak hampir sama, perbedaan utama adalah pada referensi dalam rangka produk bank konsumen tetap melihat jelas ada dua produk yang terpisah yaitu produk bank dan produk asuransi. Sementara itu dalam integrasi produk, tied product seolah-olah menyatu/ terintegrasi dengan tying product. Dengan demikian dari luar, konsumen seolah-olah hanya membeli satu produk bank (misalnya tabungan dengan pencapaian jumlah target nominal tertentu dalam waktu tertentu) yang memiliki fitur tambahan (misalnya, ada perlindungan asuransi jiwa selama jangka waktu target yang ditawarkan). Dalam rangka melindungi konsumen, BI mewajibkan pihak bank untuk menjelaskan nasbah mengenai resiko terpisah maupun hak dan kewajiban yang ditanggung oleh bank dan perusahaan asuransi mitra bank. ${ }^{36}$

Sampai pada titik ini menjadi jelas bahwa jenis bancassurance yang merupakan bentuk bundling yaitu referensi dalam rangka produk bank dan

Lihat Bagian I.1.c. SE BI No. 12/35/DPNP. Ibid.

Lihat bagian II.C.3.a. SE BI No. 12/35/DPNP.

Ibid. huruf b.

Ibid. huruf d. 
integrasi produk. Dilihat dari the focus of bundling keduanya merupakan bundling product dan dilihat dari the form of bundling keduanya merupakan pure bundling atau disebut juga tying.

Selanjutnya, menjadi pertanyaan penting untuk dijawab mengenai apakah praktik bancassurance dengan cara pure bundling product atau tying seperti ini melanggar hukum persaingan usaha. Apabila merujuk pada Pasal 15 ayat 2 UU Persaingan Usaha, unsur yang membentuk hanyalah adanya perjanjian antara pelaku usaha satu dengan pelaku usaha lain dan adanya kewajiban pembeli untuk membeli barang dan/ atau jasa lain dari perusahaan pemasok. Apabila unsur ini saja yang dipakai dalam menilai adanya tying sebagai bagian dari perjanjian tertutup, ${ }^{37}$ maka bancassurance memenuhi unsur pasal 15 UU Persaingan Usaha. Namun demikian sebagai konsekuensi logis dari pendekatan rule of reason yang dipakai maka sesuai dengan Peraturan KPPU
No. 5 Tahun 2011 mengenai pedomanan penafsiran pasal 15 UU Persaingan Usaha, untuk menganalisis adanya perjanjian tertutup harus dibuktikan dengan mempelajari latar belakang dibuatnya perjanjian tertutup tersebut serta menganalisis dampak dari dilaksanakannya hak-hak dan kewajiban-kewajiban para pihak yang lahir dari perjanjian tersebut. ${ }^{38}$ Oleh karenanya perlu digunakan kriteria sebagai tolok ukur adanya pelanggaran pasal 15 ayat 2 UU Persaingan Usaha.

\section{Dengan demikian untuk}

menentukan terjadinya pelanggaran bancassurance perlu dianalisi kasus per kasus. Namun demikian apabila dilihat kriteria dalam Peraturan KPPU ${ }^{39}$ maka kriteria pada huruf c yang mengenai syarat produk yang dijual secara tying harus merupakan produk yang terpisah jelas terpenuhi. Kemudian kriteria pada huruf a.b.d terkait dengan adanya kekuatan pasar yang signifikan, di mana ukuran kekuatan paar yang signifikan

37 Hal ini digunakan oleh investigator dalam kasus bank BRI (Perkara Nomor 05/KPPU-I/2014) yang baru mulai disidangkan di KPPU pada tanggal 2 April 2014. "Dari Laporan Dugaan Pelanggaran yang dibacakan oleh Investigator tersebut diketahui bahwa dugaan elanggaran Pasal 15 ayat (2) Undang-Undang Nomor 5 Tahun 1999 terbukti dengan adanya Perjanjian KPR BRI yang dibuat antara Terlapor I selaku pelaku usaha dengan debitur KPR BRI selaku pihak lain. Perjanjian KPR BRI tersebut terbukti memuat persyaratan bahwa debitur KPR BRI selaku pihak yang menerima barang tertentu berupa KPR BRI, diwajibkan membeli barang lain yaitu dengan membayar premi untuk asuransi jiwa dari Konsorsium Terlapor II dan Terlapor III selaku pelaku usaha pemasok. Maka dengan demikian seluruh unsur Pasal 15 ayat (2) terpenuhi." <http://www.kppu.go.id/id/2014/04/dugaan-perjanjian-tertutup-danpenguasaan-pasar-oleh-bri/> Diakses 19 April 2014.

38 Bab IV.3. Lampiran Peraturan Komisi Pengawas Persaingan Usaha Nomor 5 Tahun 2011 tentang Pedoman Pasal 15 (Perjanjian Tertutup) Undang-Undang Nomor 15 Tahun 1999 tentang Larangan Praktek Monopoli dan Persaingan Usaha Tidak Sehat 22.

39 Kriterianya adalah: a) Perjanjian tertutup yang dilakukan harus menutup volume perdagangan secara substansial atau mempunyai potensi untuk melakukan hal tersebut; b) Perjanjian tertutup dilakukan oleh pelaku usaha yang memiliki kekuatan pasar, dan kekuatan tersebut dapat semakin bertambah karena strategi perjanjian tertutup yang dilakukan; c) Dalam perjanjian tying, produk yang diikatkan dalam suatu penjualan harus berbeda dari produk utamanya; d) Pelaku usaha yang melakukan perjanjian tying harus memiliki kekuatan pasar yang signifikan sehingga dapat memaksa pembeli untuk membeli juga produk yang diikat. 
adalah pasal 4 UU Persaingan Usaha, ${ }^{40}$ maka pelanggaran baru muncul bila bancassurance mengakibatkan adanya pengusaan $75 \%$ dari pangsa pasar. Melihat pada kriteria ini, nampaknya tidak ada bank ataupun perusahaan asuransi pelaku bancassurance yang terancam melanggar perjanjian tertutup karena pada faktanya tidak ada satupun bank atau perusahaan asuransi di Indonesia yang memiliki market share lebih dari 30\%. ${ }^{41}$ Namun hal ini mungkin saja berubah mengingat asuransi terus mengalami pertumbuhan dalam kurun waktu lima tahun terakhir. ${ }^{42}$ Tingkat pertumbuhan rata-rata premi industri asuransi di Indonesia dalam lima tahun terakhir ini menurut Laporan Perasuransian (2011) adalah sebesar $21,4 \% .^{43}$

Selanjutnya apabila dilihat kemungkinan pelanggaran Pasal 19 huruf a UU Persaingan Usaha, maka apabila ada perjanjian antara bank dan perusahaan asuransi mitra secara eksklusif dapat menghalangi perusahaan asuransi lain untuk melakukan kegiatan usaha di pasar bersangkutan. ${ }^{44}$ Namun demikian harus diingat bahwa Pasal 19 UU Persaingan Usaha juga menggunakan pendekatan rule of reason sehingga mensyaratkan bahwa perjanjian yang dibuat tersebut mengakibatkan terjadinya praktik monopoli dan persaingan usaha tidak sehat. ${ }^{45}$ Dihubungkan dengan Pasal 17 ayat (2) huruf c UU Persaingan Usaha, dikatakan bahwa monopoli terjadi jika ada penguasaan pasar sebesar lebih dari $50 \%$ oleh satu pelaku usaha atau satu kelompok pelaku usaha. Dengan demikian, perjanjian eksklusif dalam bancassurance harus dipastikan dapat membuat bank atau perusahaan asuransi menguasai pasar lebih dari $50 \%$ sehingga berada dalam posisi monopoli. Namun demikian melihat pada market share perusahaan asuransi,

40 Ukuran kekuatan pasar yang dipakai adalah UU Persaingan Usaha dan bukan Peraturan KPPU karena secara hirarki UU Persaingan Usaha berada dalam tataran yang lebih tinggi sehingga peraturan dibawahnya termasuk Peraturan KPPU harus merujuk pada UU ini.

41 Pada tahun 2010, Bank Mandiri sebagai bank dengan market share tertinggi hanya menguasai $13,65 \%$ disusul dengan BRI dengan market share 13,140\% dan BCA 10,750\%. Kompas Online, 'Inilah 10 Besar Bank di Indonesia' <http://bisniskeuangan.kompas.com/read/2011/02/14/ 1707069/Inilah.10.Besar.Bank.di.Indonesia> diakses 19 April 2014. Rina Hutajulu, 'AIA Menempati Peringkat 2 Pangsa Pasar Asuransi Jiwa di Indonesia' <http://www.themarketeers.com/archives/aia-menempati-peringkat-2-di-pangsa-pasar-asuransi-jiwaindonesia.html\#.U1GGyodD-JQ> diakses 19 April 2014.

42 Hendrisman Rahim, Op.Cit. 15.

43 Ibid. 9.

44 Pasal 1 angka 10 UU Persingan Usaha: "Pasar bersangkutan adalah pasar yang berkaitan dengan jangkauan atau daerah pemasaran tertentu oleh pelaku usaha atas barang dan atau jasa yang sama atau sejenis atau substitusi dari barang dan atau jasa tersebut.“

45 Investigator dalam kasus bank BRI (Perkara Nomor 05/KPPU-I/2014) yang disidangkan di KPPU pada tanggal 2 April 2014. Syarat penguasaan pasar dikaitkan pada adanya akibat terjadi praktik monopoli dan persaingan usaha tidak sehat. Investigator KPPU mengatakan: "Pasal 19 huruf a Undang-Undang Nomor 5 Tahun 1999 telah terbukti karena Terlapor I melakukan kegiatan bancassurance bersama dengan pelaku usaha lain yaitu Terlapor II dan Terlapor III, yang menolak dan atau menghalangi perusahaan asuransi jiwa lain untuk melakukan kegiatan usaha yang sama pada pasar produk asuransi jiwa bagi debitur KPR BRI di seluruh wilayah Indonesia." <http://www.kppu.go.id/id/2014/04/dugaan-perjanjian-tertutup-danpenguasaan-pasar-oleh-bri/> diakses 19 April 2014. 
maka dapat dikatakan bahwa sampai saat ini tidak ada ada potensi terjadinya praktik monopoli dan persaingan usaha tidak sehat dalam bancassurance. ${ }^{46}$

Pada akhirnya dapat dikatakan bahwa bancassurance dalam bentuk pure bundling product berpotensi dalam skala yang sangat kecil (mengingat fakta market share perbankan) menyebabkan terjadinya praktik monopoli dan persaingan usaha yang tidak sehat. Namun demikian, potensi yang sangat kecil ini dapat berubah jika asuransi berkembang dengan pesat dan terdapat perusahaan asuransi - dari antara 137 perusahaan asuransi yang ada (sampai akhir September 2013) ${ }^{47}$ - secara mengejutkan mampu menguasai pasar.

\section{PENUTUP}

Praktik bancassurance di dunia perbankan dalam bentuk bundling terdiri dari kerjasama pemasaran dengan jenis referensi dalam rangka produk bank dan integrasi produk. Dilihat dari fokusnya, keduanya merupakan bundling product dan dilihat dari bentuknya keduanya merupakan pure bundling atau tying. Pada dasarnya penjualan secara bundling tidak dilarang, namun demikian pelaku usaha perlu berhati-hati agar tidak melanggar pasal 15 ayat (2) UU Persaingan Usaha mengenai perjanjian tertutup dan Pasal 19 huruf b UU Persaingan Usaha mengenai penguasaan pasar. Melihat pada kondisi perbankan dan perasuransian Indonesia, tidak ada satu pelaku usaha pun yang menguasai pangsa pasar sampai dalam persentase yang dilarang, oleh karenanya praktik bancassurance pada saat ini tidak melanggar hukum persaingan usaha akan tetapi memiliki potensi yang kecil akan menciptakan praktik monopoli dan persaingan usaha tidak sehat.

\section{DAFTAR BACAAN}

\section{Jurnal}

Ahlborn, Christian, dan David S. Evans, 'The Microsoft Judgement and its Implication for Competition Policy towards ominant Firms in Europe' 75 Antitrust Law Journal 1. <http:/ /ssrn.com/abstract $=1115867$ > diakses 18 April 2014.

Bork, Robert H., dan J. Gregory Sidak, 'What Does The Chicago School Teach About Internet Search and The Antitrust reatment of Google?' (2012) 8 Journal of Competition Law \& Economics 663.

Derdenger, Timoty, dan Vineet Kumar, 'The Dynamic Effects of Bundling as a Product Strategy' (2013) 32 Marketing Science Journal 827.

46 Menurut survei Frontier Consulting Group, perusahaan asuransi Prudential memiliki market share paling tinggi (25.8\%) pada tahun 2012. Lihat, Suhartono Chandra, 'Brand Diagnostic dan Hasil Pengukuran Top-Brand Index - Analisis pada Industri Asuransi' Jiwa. <http:// www.frontier.co.id/brand-diagnostic-dan-hasil-pengukuran-top-brand-index-analisis-padaindustri-asuransi-jiwa.html> diakses 22 April 2014.

47 Otoritas Jasa Keuangan, Laporan Triwulan III Tahun 2013, 17. 
Economides, Nicholas, dan Ioannis Lianos, The Elusive Antitrust Standard on Bundling in Europe and In The United States in The Aftermath of The Microsoft Cases' (2009) 76 Antitrust Law Journal 483.

Nugroho, Ahmad Adi, 'Strategi Bundling/Tying Sebagai Upaya Abuse of Dominance: Studi Kasus Penerapan Tying/Bundling oleh Microsoft' ( 2010) 3 Jurnal Persaingan Usaha KPPU 53.

Rahim, Hendrisman, 'Optimisme Pertumbuhan Asuransi Indonesia; Proyeksi Perkembangan Lima Tahun (2014-2018)' (2013) 1 Jurnal Asuransi dan Manajemen Resiko 1.

Strernersch, Stefan, dan Gerard J. Tellis, 'Strategic Bundling of Products and Prices: A New Synthesis for Marketing' (2002) 66 Journal of Marketing 55.

\section{Internet}

Chandra, Suhartono, 'Brand Diagnostic dan Hasil Pengukuran TTop-Brand Index - Analisis pada Industri Asuransi Jiwa'<http:// www.frontier.co.id/branddiagnostic-dan-hasil-pengukurantop-brand-index-analisis-padaindustri-asuransi-jiwa.html> diakses 22 April 2014.

European Commission, 'Commission Concludes on Microsoft Investigation, Imposes Conduct Remedies and a Fine' <http:// e $\mathrm{u}$ r o p a e u / r a p i d / pressReleasesAction.do?reference=IP/ 04/3 $82 \&$ f o r m a t $=$ H T M L \& a $\mathrm{g}$ e $\mathrm{d}=0$ \& 1 a $\mathrm{n}$ g u a g e $=$ EN\&guiLanguage $=e n>$ diakses 18 April 2014.

FAT, 'OJK Minta Bancassurance Terbuka Bagi Asuransi lain. Jika Tak Terbuka Bagi Industri Asuransi Lain, maka Tidak Fair' (2014) <http:// www.hukumonline.com/berita/ baca/lt5333e8bae1daf/ojk-mintabancassurance-terbuka-bagiasuransi-lain> diakses 17 April 2014.

Pradita, Ilyas Istianur, 'Strategi Bisnis Bancassurance berpotensi picu monopoli (2014) <http:// bisnis.liputan 6.com/read/ 2028883 / strategi - bis nis bancassurance-ri-berpotensi-picumonopoli> diakses 17 April 2014.

Yudanov, 'Dugaan Perjanjian Tertutup dan Penguasaan Pasar oleh BRI' <http://www.kppu.go.id/id/2014/ 04/dugaan-perjanjian-tertutup-danpenguasaan-pasar-oleh-bri/> diakses 17 April 2014. 